\title{
Professional Learning Communities Approach: Implications for Policy and Practice
}

\author{
Osama Al Mahdi \\ Bahrain Teachers College, University of Bahrain
}

\section{Introduction}

Over the last decades researching and developing teachers' professional development frameworks and practices had underwent a paradigm shift. This shift was driven by the complexities of teaching and learning requirements, an increased necessity for reforming educational systems, and more need for accountability and quality outcomes (Vescio, Ross EO Adams, 2007). The main feature of these new approaches is that they shift professional development beyond merely focusing on a teacher's simple attainment of knowledge and skills to a framework that requires teachers to deeply reflect on their own practices, to innovate new classroom pedagogy, and authentic understanding and expectations of student outcomes (Darling-Hammond \& $\mathrm{McL}$-aughlin, 1995).These new approaches of teacher professional development include a variety of practitioner-based activities such as: peer observation and assessment, working cooperatively on shared projects such as curriculum development or strategy planning, engaging in lesson study groups, conducting action research, and participating in individually guided activities such as online distant learning or academic higher educational programs. When teachers engage in professional development activities that entail sharing questions, finding answers, experimenting practical actions and engaging in a productive dialogue, this may promote their sense of belonging as knowledge workers in their professional learning communities, and this would support them in achieving their learning and teaching goals which would reflect at the end on their students' knowledge, skills and values (Al-Mahdi, 20I9a, Al-Mahdi, 20Igb, Al-Mahdi E Al-Wadi, 20I5). This chapter aims to explore professional learning community as an innovate approach in teachers' professional development and discuss possible ways for implementing it in Bahrain 
This is a limited preview of the chapter.

To read the full-text chapter, get access by purchasing this chapter or consider buying the complete book. If your library has subscription to EBSCOhost, the chapter including other chapters of the book can be accessed through your library.

This chapter is a part of the book, 'Innovations in Educational Leadership and Continuous Teachers' Professional Development' ISBN (paperback): 978-8I-948483-2-5; ISBN (ebook): 978-8I' $948483-3-2$

Book DOI: https://dx.doi.org/ro.46679/isbn9788194848325 Chapter DOI: https://dx.doi.org/I0.46679/isbn978819484832509 
for teachers. In addition, these studies can provide evidence for decisionmakers regarding the usefulness and feasibility of applying professional learning communities and may lead to the development of new trends in this field that are appropriate to the nature and context of educational systems in our local communities that are suitable to the conditions, needs and nature of schools (governmental or private).

Bahrain Teachers College can also play an important role in promoting the use of professional learning communities by allocating courses specific to this educational approach for students who are doing their studies in the baccalaureate stage so that future graduates are prepared to employ professional learning communities in their classrooms and schools.

\section{References}

Al-Mahdi, O. (20I9 a). Action research and teachers' professional development: Examples and Reflections. International Education Research, 3 (2), 37-46.

Al-Mahdi, O. (20Igb). Using action research in teachers' professional development. In S. Sharma छ T. Chuanmao. Contemporary Advances in Education. India: CSMFL Publications. (Page I-I5).

Al-Mahdi, O. E Al-Wadi, H. (20I5). Towards a sociocultural approach on teachers' professional development in Bahrain. Journal of Teaching and Teacher Education, 3 (I), 89-100.

Al-Mahdi, O. E' Bukamal, H. (20I9). Pre-Service Teachers' Attitudes Toward Inclusive Education During their Studies in Bahrain Teachers College. Sage Open, July, September, I-I4.

Al-Mahdy, Y., E Sywelem, M. (20I6). Teachers' perspectives on professional learning communities in some Arab countries. International Journal of Research Studies in Education, 5 (4), 45-57.

Al-Taneiji, S. (2009). Professional learning communities in the United Arab Emirates schools: realities and obstacles. International Journal of Applied Educational Studies, 6 (I), I6- 26.

Bailey, L., Purinton, T., Al-Mahdi, O. छ Al Khalifa, H. (20I9). Conceptualizing school leadership in the Gulf Cooperation Council (GCC) cultures: Demarcating challenges for research. Educational Management Administration छ? Leadership, November, I:I9.

Barth, R. (I990). Improving schools from within. San Francisco: Jossey-Bass.

Bolam, R., McMahon, A., Stoll, L., Thomas, S., Wallace, M., Greenwood, A.,Hawkey, K., Ingram, M., Atkinson, A. छ Smith, M. (2005). Creating and sustaining effective 
professional learning communities. Research Report 637. London: DfES and University of Bristol.

Carpenter, D. (2015). School culture and leadership of professional learning communities. International Journal of Educational Management, 29 (5), 682-694.

Chen, P., Lee, C., Lin, H. छ Zhang, C. (20I6). Factors that develop effective professional learning communities in Taiwan. Asia Pacific Journal of Education, 36 (2), 248-265.

Darling-Hammond, L., \& McLaughlin, M. (1995). Policies That Support Professional Development in an Era of Reform. Phi Delta Kappan, 76 (8), 597-604.

DuFour, R. (2004). What Is a Professional Learning Community?. Educational Leadership, 6I (8), 6-II.

Evers, J., छ R. Kneyber, eds. 20I5. Flip the System: Changing Education from the Ground up. In Hargreaves, A., and M. Fullan. 20I2. Professional Capital: Transforming Teaching in Every School. New York: Teachers College Press.

Harris, A. EJ Jones, M. (2017). Leading professional learning: putting teachers at the centre, School Leadership E̋ Management, 37 (4), 331-333.

Jensen, B., Sonnemann, J., Roberts-Hull, K. छ̋ Hunter, A. (20I6). Beyond PD: Teacher Professional Learning in High-Performing Systems. Washington, DC: The National Center on Education and the Economy.

Kyndt, E., Gijbels, D., Grosemans, I., छ̋ Donche, V. (20I6). Teachers' everyday professional development: Mapping informal learning activities, antecedents, and learning outcomes. Review of Educational Research, 86 (4), IIII-II5O.

Lee, M. छ' Kim, J. (20I6) The emerging landscape of school-based professional learning communities in South Korean schools. Asia Pacific Journal of Education, 36 (2), 266, 284 .

Mindich, D., छु Lieberman, A. (20I2). Building a learning community: A tale of two schools. Stanford. CA: Stanford Center for Opportunity Policy in Education.

Myers, C. EJ Simpson, D. (I998). Re-creating schools: Places where everyone learns and likes it. Thousand Oaks, CA: Crowin Press.

Olivier, D. छ Huffman, J. (20I6). Professional learning community process in the United States: conceptualization of the process and district support for schools. Asia Pacific Journal of Education, 36 (2), 30I-3I7.

Roberts, S. \& Pruitt, E. (2009). Schools as professional learning communities: Collaboration activities and strategies for professional development. London: Crowin Press, SAGE.

Roy, C. (20I6). A Professional Learning Community with an Arabian Twist. (Master's thesis, Northwestern College, Orange City, IA).Retrieved from http://nwcommons.nwciowa.edu/education_masters/7/

Salleh, H. (20I6). Facilitation for professional learning community conversations in Singapore. Asia Pacific Journal of Education, 36 (2), 285-300.

Seashore, K. Anderson, EJ A. Riedel. (2003). Implementing arts for academic achievement: The impact of mental models, professional community, and interdisciplinary learning. 
Minneapolis, MN: Center for Applied Research and Educational Improvement, University of Minnesota.

Senge, P. (1990). The fifth discipline: The art and practice of learning organization. New York: Doubleday.

Senge, P. (1994). The fifth discipline field book: Strategies and tools for building a learning organization. New York: Doubleday.

Stoll, L., Bolam, R. McMahon, A. Wallace, M. छ Thomas. S. (2006). Professional learning communities: A review of the literature. Journal of Educational Change 7 (4): 22I-59.

Sun-Keung Pang, N., Wang, T. E Leung, Z. (2016). Educational reforms and the practices of professional learning community in Hong Kong primary schools. Asia Pacific Journal of Education, 36 (2), 23I-247.

Underwood, M. (20I5).Understanding professional community and professional identity through the experiences of Bahraini teachers working with British teachers in a partnership project. Paper presented to: European Conference on Educational Research (ECER): Education and Transition - Contributions from Educational Research, Corvinus University, Budapest, 08-II September 2015.

Vangrieken, K., Meredith, C., Packer, T., छ Kyndt, E. (20I7). Teacher communities as a context for professional development: A systematic review. Teaching and Teacher Education, 6I, 47-59.

Vescio, V., Ross, D., छु Adams, A. (2007). A review of research on the impact of professional learning communities on teaching practice and student learning. Teaching and Teacher Education, 24, 80-9I.

Wang, T. (20I6). School leadership and professional learning community: case study of two senior high schools in Northeast China. Asia Pacific Journal of Education, 36 (2), 202, 216.

Zhang, J. E. Sun-Keung Pang, N. (20I6). Investigating the development of professional learning communities: compare schools in Shanghai and Southwest China. Asia Pacific Journal of Education, 36 (2), 217-230. 